\title{
The methods of evaluating storage volume for single-chamber reservoir in urban catchments
}

\author{
Bartosz Szeląg ${ }^{1 *}$, Maciej Mrowiec² \\ ${ }^{1}$ Kielce University of Technology \\ Faculty of Environmental, Geomatic and Energy Engineering \\ ${ }^{2}$ Częstochowa University of Technology \\ Faculty of Environmental Engineering and Biotechnology \\ *Corresponding author's e-mail: bartoszszelag@op.pl
}

Keywords: SWMM, stormwater, reservoir volume.

\begin{abstract}
The article presents a method of designing single-chamber rectangular detention reservoirs based on nomographs connecting the parameters and the shape of the inflow with the reservoir hydrograph (triangular, described by the power function and described by the gamma distribution) as well as the hydraulic characteristics of the accumulation chamber and the orifice. The preparation of nomographs involved using the SWMM (Storm Water Management Model) program with the application of numerical calculations' results of a differential equation for the stormwater volume balance. The performed analyses confirm a high level of similarity between the results of calculating the reservoir volume obtained by using the above mentioned program and using the developed nomographs. The examples of calculations presented in the paper confirm the application aspects of the discussed method of designing the detention reservoir. Moreover, based on the conducted analyses it was concluded that the inflow hydrograph described by the gamma distribution has the greatest impact on the reservoir's storage volume, whereas the hydrograph whose shape in the rise and recession phases is described by the power function has the smallest effect.
\end{abstract}

\section{Introduction}

The development of conurbations as well as the process of drainage systems ageing lead to numerous problems with draining rainwater from urbanized catchments. They result in the intensification of catchments' flooding, which causes traffic paralysis and financial losses. Solving these problems by increasing the diameters of pipes usually lacks economic justification. It is more beneficial to build storage reservoirs (Kisiel 2007, Mrowiec 2009, Malmur 2013, Licznar 2013), which temporarily capture a part of the inflow hydrograph volume, causing a reduction in the maximum flow rates as well as their delay. The basis for storage reservoir dimensioning is the inflow hydrograph, which also constitutes the grounds for selecting the type and dimensions of the outlet orifice.

Currently, graphical methods based on numerical solving of the differential equation are becoming increasingly popular, due to the fact that they allow for relatively quick determination of the required reservoir volume, while also being highly precise. Nevertheless, other methods are being developed as well, wherein the hydrograph of the reservoir outflow is schematized using a triangle, rectangle or trapezium (Guo 1999, Akan and Houghtalen 2003, Hong et al. 2006).

The existing methods of sizing reservoirs relatively rarely take into account the hydrograph shape (Hager and Sinninger 1985, Akan and Houghtalen 2003, Hong 2009, Graber 2009), and in many methods it is disregarded (Baker 1979, SCS 1986). Moreover, numerous simplifying assumptions in various methods lead to a considerable difference in the obtained results (Szeląg and Kiczko 2014), which in practice hinders the selection of a method appropriate for calculating the required reservoir volume. Considering the above, it is advisable to further develop the methods of sizing reservoirs that take into account the inflow shape, and at the same time eliminate the need to apply complex numerical algorithms for solving the differential equation for the volume balance.

This article presents a simple method of calculating the volume of a rectangular reservoir, taking into account the inflow hydrograph shape based on the nomograph connecting the hydrograph parameters with the dimensions of the reservoir equipped with an orifice as the outflow controller. The discussed method permits the consideration of the effect that the triangular hydrograph, as well as the one described by the power function and the one described by the gamma distribution have on the reservoir volume.. The development of nomographs involved using the SWMM (Storm Water Management Model) program with the application of numerical calculation results of the reservoir volume. Certain exemplary calculations taking into account the inflow hydrograph shapes, analyzed in the process of the detention reservoir designing, have been performed in order to present the developed methodology. 


\section{Inflow hydrograph}

The process of surface runoff forming is a complex phenomenon, affected by numerous factors (Gironàs et al. 2009, Dayarante and Perrera 2004, 2008, Shuster et al. 2005), therefore engineering calculations are based on a number of simplifications. Consequently, the hydrographs of outflows from drainage areas are schematized and volumes of reservoirs are calculated using the hydrographs of the following shapes:

- triangular (Abt and Grig 1978, Basha 1995, Gomez et al. 2001, Hong 2008,),

- trapezoidal (Burton 1980, Aron and Kibler 1990, Guo 1999, Hong et al. 2006, Graber 2009, Froehlich 2009),

- defined by gamma probability density function (Kessler and Diskin 1991, McEnroe 1992, Akan and Houghtalen 2003),

- curvilinear $(\mathrm{Q}=\mathrm{f}(\mathrm{t})$ in the SCS method (Akan 1990)).

The completed research (ATV A - 118, TPGWRD 1993, United States Department of Agriculture 1986, Mrowiec 2009, Banasik et al. 2014) confirms that the hydrograph of outflow from a small catchment, i.e. with the surface of up to 200 ha, caused by a short-term intensive rainfall can be defined using a triangle, a power function or the gamma distribution. The application of this sort of parameterization in the reservoir sizing, in order to define the rate of stormwater inflow and outflow, is presented by Guo (1999), Yao - Ming Hong (2008), Akan and Houghtalen (2003), as well as Szeląg and Kiczko (2014). In the case of a catchment with an area of above 200 ha or when the time of the stormwater runoff exceeds 15 minutes, it is advised to use hydrodynamic models in hydrograph calculations (Djordjević et al. 2005, Seo et al. 2013, Bach et al. 2014). Since the hydrograph shapes vary, the following parameters were introduced into the description of the irregular stormwater volume distribution in the inflow hydrograph in order to generalize this variability in the practical discussion: $\mathrm{S}=\mathrm{V}_{\mathrm{p}} / \mathrm{V}_{\mathrm{c}}$ (where: $\mathrm{V}_{\mathrm{p}}$ - rise phase volume, $\mathrm{V}_{\mathrm{t}}$ - total inflow hydrograph volume) and $\omega=\mathrm{Q}_{\mathrm{pmax}} \cdot \mathrm{t}_{\mathrm{p}} \cdot \mathrm{V}_{\mathrm{t}}^{-1}$.

\section{Theoretical background}

\section{of sizing the reservoir volume}

The methods of the storage reservoir designing are based on a principle applied in hydrology, i.e. the comparison of the inflow and outflow variables graphs (Linsley et al. 1958, Chow et al. 1988, Fenton 1992, Basha 1995, Fiorentini and Orlandini 2013). The first solution involves determining the surface area

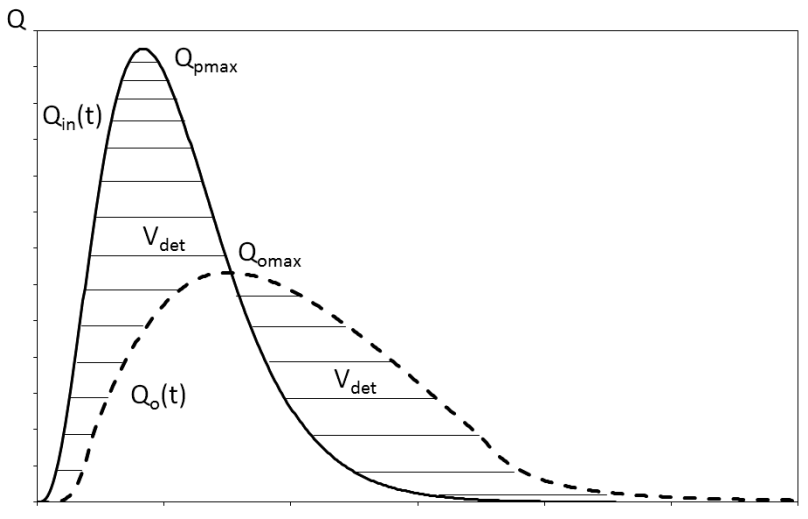

$\mathrm{t}$ of a figure formed by the hydrographs: the inflow $\mathrm{Q}_{\text {in }}(\mathrm{t})$ one and the outflow $\mathrm{Q}_{\mathrm{o}}(\mathrm{t})$ from the storage reservoir (Fig.1a) one. The second solution is the modification of the first one and consists in plotting cumulative curves for the inflow $\mathrm{V}_{\text {in }}(\mathrm{t})$ and outflow $\mathrm{V}_{\mathrm{o}}(\mathrm{t})$ from the reservoir (Fig. 1b).

The relation between the variability in the volume of stormwater accumulated in the rectangular basin $\mathrm{V}(\mathrm{t})$ and the intensity of the inflow $Q_{d}(t)$ and the discharge of a small circular orifice $Q_{0}(t)$ can be expressed with the differential equation for the volume balance in the following form:

$$
\frac{d V}{d t}=Q_{p \max } \cdot f(t)-\frac{C_{\text {out }}}{A^{0,50}} \cdot V^{0,50}
$$

where: $\mathrm{Q}_{\text {pmax }}$ - maximum inflow to the reservoir $\left(\mathrm{m}^{3} \cdot \mathrm{s}^{-1}\right), \mathrm{f}(\mathrm{t})$ - function taking into account the inflow hydrograph shape, $\mathrm{V}$ - volume of stormwater accumulated in the basin $\left(\mathrm{m}^{3}\right)$, $\mathrm{dV}$ - change stormwater volume in the reservoir in time $\mathrm{dt}$ $\left(\mathrm{m}^{3}\right), \mathrm{A}-$ basin surface area in plan $\left(\mathrm{m}^{2}\right), \mathrm{C}_{\text {out }}$ - parameter describing the characteristics of the orfice expressed as $\mathrm{C}_{\text {out }}=\mu \cdot \pi \cdot 4^{-1} \cdot \mathrm{D}_{\text {out }}^{2} \cdot(2 \cdot \mathrm{g})^{0,50}\left(\mathrm{~m}^{2,5} / \mathrm{s}\right)$.

In order to transform the equation (1) into a dimensionless form, the following normalizing parameters were introduced (McEnroe 1992, Akan and Houghtalen 2003):

- dimensionless time from the beginning $\left(\mathrm{t}^{*}\right)$

$$
\mathrm{t}^{*}=\frac{\mathrm{t}}{\mathrm{t}_{\mathrm{p}}}
$$

- dimensionless inflow $\left(\mathrm{Q}_{\text {in }}{ }^{*}\right)$

$$
Q_{i n}^{*}=\frac{Q_{i n}}{Q_{p \max }}
$$

- dimensionless reservoir volume $\left(\mathrm{V}^{*}\right)$

$$
V^{*}=\frac{V}{V_{t}}
$$

where: $t_{p}$ - rise phase time, $V_{t}$ - inflow hydrograph volume, $\mathrm{Q}_{\text {pmax }}$ - peak flow.

V

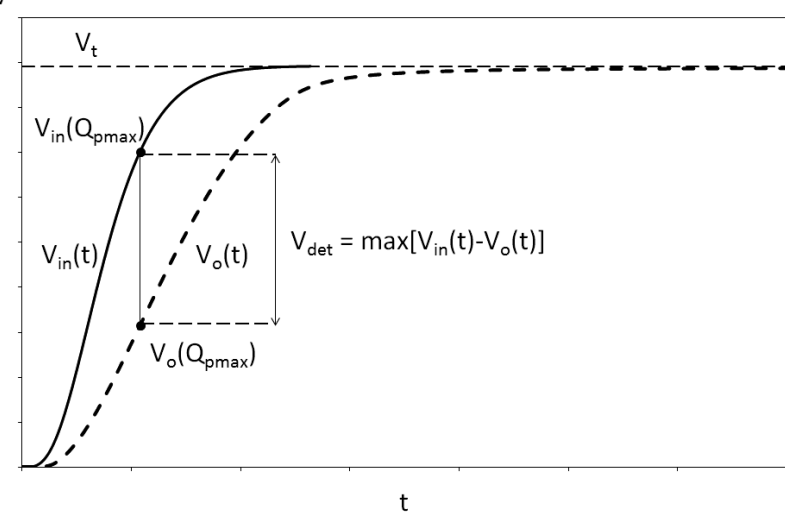

Fig. 1. Diagram depicting methods of calculating the storage reservoir capacity based on: a) inflow and outflow hydrograms, b) inflow and outflow cumulative curves 
Substituting (2), (3), (4) into (1) one obtains a dimensionless differential equation in the form:

$$
\frac{\mathrm{dV}^{*}}{\mathrm{dt}^{*}}=\omega \cdot \mathrm{f}\left(\mathrm{t}^{*}\right)-\mathrm{R} \cdot\left(\mathrm{V}^{*}\right)^{0,50}
$$

where: $\mathrm{R}$ - parameter taking into account the characteristics of the reservoir and the inflow hydrograph expressed as:

$$
R=\frac{C_{\text {out }} \cdot t_{p}}{\sqrt{A \cdot V_{t}}}=\frac{\pi \cdot \sqrt{2 \cdot g} \cdot \mu \cdot t_{p} \cdot D_{o u t}^{2}}{4 \cdot \sqrt{A \cdot V_{t}}}
$$

$\omega$ - parameter of the inflow hydrograph shape described as:

$$
\omega=\frac{Q_{p \max } \cdot t_{p}}{V_{t}}
$$

Taking into account the relations presented above, it can be stated that sizing a single-chamber reservoir with a predetermined surface area in plan and the predefined diameter of the orifice opening with an inflowing hydrograph of the predetermined parameters, is reduced to a dimensionless volume balance equation (5), wherein the dimensionless reservoir volume is the function of the parameters $\omega$ and $\mathrm{R}$ and the function $\mathrm{f}\left(\mathrm{t}^{*}\right)$.

\section{Research methodology}

The volume of the storage reservoir was calculated using three shapes of inflow hydrographs (triangular, defined with the power function and gamma probability density distribution) with the constant inflow volume $\left(\mathrm{V}_{\mathrm{t}}=3724 \div 45000 \mathrm{~m}^{3}\right)$ and the peak inflow $\left(\mathrm{Q}_{\mathrm{pmax}}=2.58 \div 10.00 \mathrm{~m}^{3} / \mathrm{s}\right)$. The peak time ranged from $\mathrm{t}_{\mathrm{p}}=5 \mathrm{~min}$ to $150 \mathrm{~min}$. The values of the analyzed hydrograph asymmetry coefficients $(\mathrm{S})$ ranged from 0.10 to 0.50 with the parameter $\omega$ as follows: for the triangular inflow hydrograph $\omega=0.20 \div 1.00$, for the one defined with the power function $\omega=0.32 \div 3.73$ and for the gamma distribution one $\omega=0.11$ $\div 1.78$. The calculations were made for the horizontal surface area of the reservoirs in the range of $A=1500-13300 \mathrm{~m}^{2}$ and the diameters of the bottom outlets $\mathrm{D}_{\text {out }}=0.25 \div 1.25 \mathrm{~m}$ and discharge coefficient $\mu=0.60$. The differential equation of the stormwater volume balance (4) for the rectangular reservoir was solved using the SWMM program (Storm Water Management Model).

\section{Research results}

The calculations of the reservoir volume performed in the SWMM program and the analysis of the obtained results permitted the development of the relations between the $\mathrm{R}$ parameter, the maximum flow reduction coefficient $(\beta)$ and the hydrograph asymmetry coefficient $(\omega)$ for the examined inflow hydrographs. Figure 2 presents an example of a nomograph made for a triangular inflow hydrograph.

The lines presented in figure 2 show that the value of parameter $\mathrm{R}$ is a linear function $\omega$ for known value $\beta$. Moreover, in order to maintain constant value $R$, if $\omega$ is increasing $\left(\omega_{2}>\right.$ $\left.\omega_{1}\right)$ it is necessary to reduce the peak flow reduction coefficient, which in practice means reducing the bottom outlet diameter $\left(D_{\text {out }}\right)$ and/or the discharge coefficient $(\mu)$, assuming constant horizontal surface area (A). Identical dependencies were found for nomograph obtained for an inflow hydrograph defined with power function and gamma probability density distribution.

In the case when the adopted value $\beta$ is different than those in the $\mathrm{R}=\mathrm{f}\left(\omega, \beta=\beta^{*}, \beta^{*}=\right.$ const $)$ graph, it is necessary to interpolate the values; however, this could result in an error. In order to avoid that, the relations $R=f(\omega)$ for different values of the maximum flow reduction coefficients $(\beta)$ were approximated with the $\mathrm{R}=\theta(\beta) \cdot \omega$ function. The calculations indicated that approximating the variability $\mathrm{R}=\mathrm{f}\left(\omega, \beta=\beta^{*}, \beta^{*}\right.$ $=$ const) with a linear function, the values of the coefficients of determination $\left(\mathrm{R}^{2}\right)$ for $\beta=0.1 \div 0.9$ vary in the range of $0.996 \div 0.999$. This served as the basis for determining values of parameters $\theta$ for the analyzed inflow hydrographs, and then to prepare a graph illustrating influence of $\beta$ on value $\theta$ (fig. 3). Based on the parameter dependence $\theta=f(\beta)$ (fig. 3),

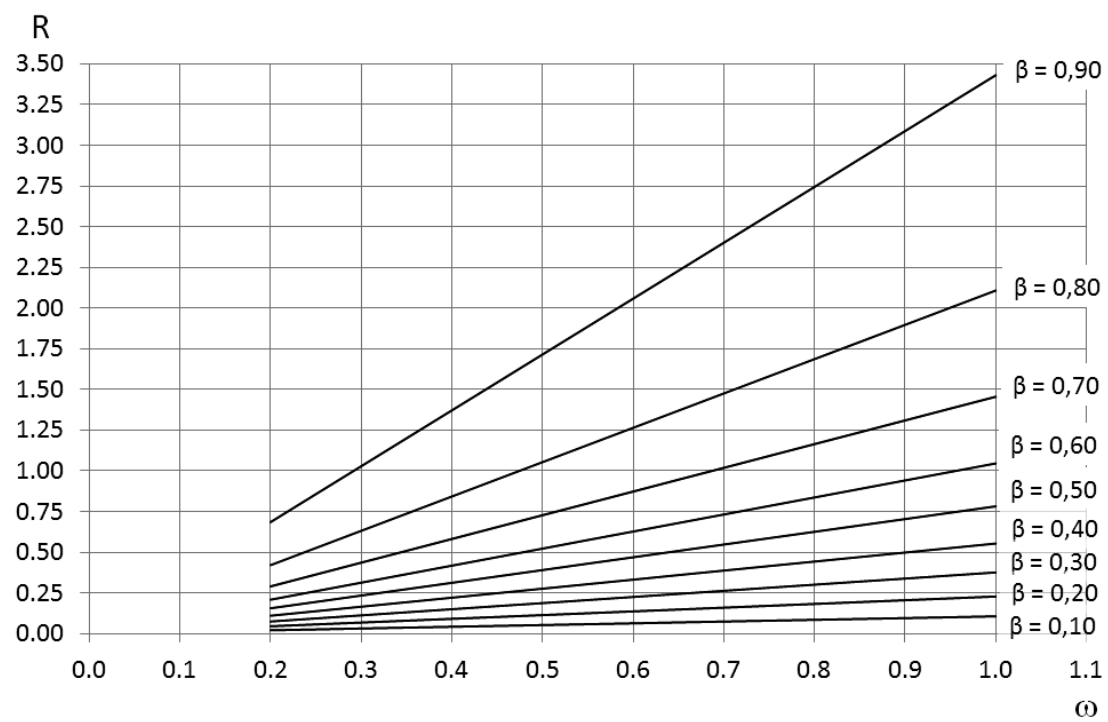

Fig. 2. Effect of hydrograph asymmetry coefficient $(\omega)$ and peak flow reduction coefficient $(\beta)$ on the value of parameter $(R)$ for triangular hydrograph 
it is possible to specify the value of parameter $\theta$ required to calculate the value of function $R=f(\omega)$, which is the base for determining the peak flow reduction coefficient. The results of the simulations carried out in the SWMM program were used to prepare graph (fig. 4) illustrating the influence of the hydrograph asymmetry coefficient and the peak flow reduction coefficient on the nondimensional volume of the storage reservoir $\left(\mathrm{V}_{\text {det }} / \mathrm{V}_{\mathrm{t}}\right)$.

The graph (fig. 4) depicting the impact of the inflow hydrograph asymmetry and the peak flow reduction coefficient on the dimensionless volume of a detention reservoir $\left(\mathrm{V}_{\mathrm{det}} / \mathrm{V}_{\mathrm{t}}\right)$ was prepared taking into consideration the obtained results of the SWMM program simulation and the developed lines (fig. 2, fig. 3). On the basis of the graph (fig. 4) it was concluded that when the share of the rise phase volume in the total hydrograph volume (triangular, described by the gamma distribution or by the power function) is $S=0.5$, then the designed reservoir volume reaches the maximum value. Moreover, it was found that for the analyzed hydrograph shapes, the growth of the asymmetry coefficient $\mathrm{S}$ leads to the increase in the required single-chamber reservoir volume (fig. 4). When the hydrograph shape for the outflow from the catchment can be described by the gamma distribution, then the value change of the stormwater volume distribution irregularity (S) has the largest impact on the volume of the designed reservoir (fig. 4), whereas for the variability $\mathrm{Q}_{\text {in }}=\mathrm{f}(\mathrm{t})$ described by the triangle the observed effect of $\mathrm{S}$ on $\mathrm{V}_{\text {det }} / \mathrm{V}_{\mathrm{t}}$ was insignificant.

For example, for $\beta=0.4$ the change in the value of $\mathrm{S}$ from 0.1 to 0.5 for the hydrograph described by gamma distribution and by the triangle leads to the increase of $\mathrm{V}_{\text {det }} / \mathrm{V}_{\mathrm{t}}$ from 0.40 to $0.57(42.5 \%)$ and from 0.47 to $0.53(13 \%)$, respectively. The smallest reservoir volume among the analyzed shapes of hydrographs (fig. 4) is achieved for the rainfall intensity distribution that conditions the occurrence of the hydrograph defined by the power function. In the case when the variability $\mathrm{Q}_{\text {in }}=\mathrm{f}(\mathrm{t})$ can be reduced to the gamma distribution, the calculated storage volume for $\beta=0.2 ; \beta=0.4 ; \beta=0.6$ and

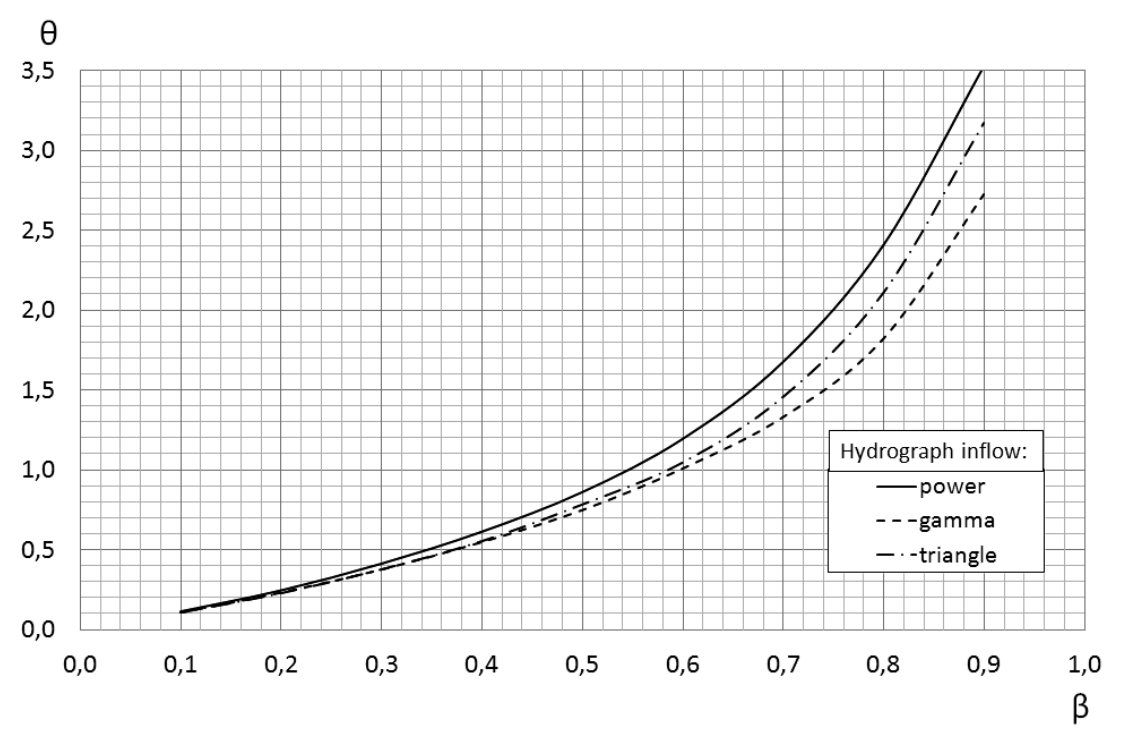

Fig. 3. Dependence of parameter $\theta=f(\beta)$

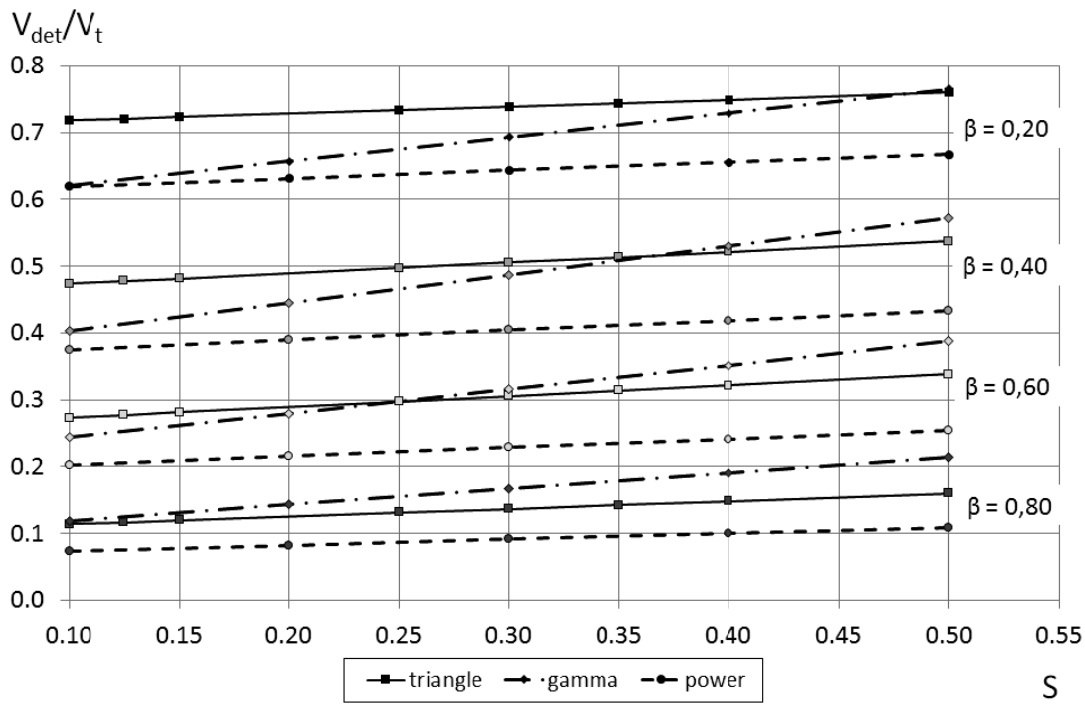

Fig. 4. The impact of the hydrograph asymmetry coefficient (S) and the peak flow reduction coefficient on the dimensionless volume of the detention reservoir $\left(\mathrm{V}_{\text {det }} \mathrm{N}_{\mathrm{t}}\right)$ for the inflow hydrographs: triangular, defined by the power function and defined by the gamma distribution 
$\beta=0.8$ are larger than $\mathrm{V}_{\text {det }}$ obtained for the triangular hydrograph when $\mathrm{S}>0.47, \mathrm{~S}>0.37, \mathrm{~S}>0.26$ and $\mathrm{S}>0.10$. Moreover, when the inflow to the reservoir can be described by the triangular hydrograph, then the largest required storage volume with respect to the shapes discussed in the paper is achieved for $\beta<0.2$ for the whole range of the analyzed asymmetry coefficient $\mathrm{S}$. In the case when the variability $\mathrm{Q}_{\text {in }}=\mathrm{f}(\mathrm{t})$ can be expressed by the gamma distribution, then for $\beta=0.8$ the obtained dimensionless reservoir volume is larger than the value $\mathrm{V}_{\text {det }} / \mathrm{V}_{\mathrm{t}}$ determined for the triangular and described by the gamma distribution hydrographs (fig. 4).

In order to illustrate the developed method, two analytical examples were made. In the first one, the storage volume was calculated for an assumed inflow hydrograph $\left(\mathrm{Q}_{\mathrm{pmax}}, \mathrm{t}_{\mathrm{p}}, \omega\right)$ and the reservoir $\left(\mu, \mathrm{A}, \mathrm{D}_{\text {out }}\right)$; in the second, the horizontal surface area was determined for the accepted value of $\beta$ and $H$.

\section{Example I}

A storage reservoir with the horizontal surface area of $\left(\mathrm{A}=600 \mathrm{~m}^{2}\right)$, bottom outlet diameter of $\left(\mathrm{D}_{\text {out }}=0.60 \mathrm{~m}\right)$, discharge coefficient of $(\mu=0.60)$ is fed by a triangular inflow hydrograph $\left(\mathrm{Q}_{\mathrm{pmax}}=3.50 \mathrm{~m}^{3} / \mathrm{s}, \mathrm{t}_{\mathrm{p}}=15 \mathrm{~min}, \mathrm{~V}_{\mathrm{t}}=3938 \mathrm{~m}^{3}\right.$, $\omega=0.8)$. In order to calculate the reservoir storage volume and maximum outflow $\left(\mathrm{Q}_{\text {omax }}\right)$ Formula (6) was used to determine the value $\mathrm{R}=3.14 \cdot 0,25 \cdot(0.6 \cdot 0.6) \cdot(15 \cdot 60) \cdot(2 \cdot 9.81)$ $0.50 /(600 \cdot 2813)^{0.5}=0.73$, and graph $R=f(\omega, \beta)$ was used to determine $\beta=0.54$ and to calculate $\mathrm{Q}_{\mathrm{omax}}=\beta \cdot \mathrm{Q}_{\mathrm{pmax}}=0.54 \cdot 3.50$ $=1.89 \mathrm{~m}^{3} / \mathrm{s}$. Next, the required volume was defined as $\mathrm{V}_{\text {det }}=1418 \mathrm{~m}^{3}$ and based on that, the filling level of the reservoir was calculated $-\mathrm{H}=2.36 \mathrm{~m}$.

\section{Example II}

A storage reservoir with the bottom outlet diameter of $\mathrm{D}_{\text {out }}=0.50 \mathrm{~m}(\mu=0.60)$ is fed by inflow hydrograph defined with gamma distribution $\left(\mathrm{Q}_{\mathrm{pmax}}=2.00 \mathrm{~m}^{3} / \mathrm{s}, \mathrm{t}_{\mathrm{p}}=10 \mathrm{~min}\right.$, $\mathrm{V}_{\mathrm{t}}=4946 \mathrm{~m}^{3}$ and $\left.\omega=0.243\right)$; and the peak flow reduction coefficient comes to $\beta=0.50$.

Nomograph $\theta=\mathrm{f}(\beta)$ (fig. 3) was used to determine value $\mathrm{R}=0.74$ for $\beta=0.50$. In order to calculate the horizontal surface area of the reservoir, equation (6) was transformed into:

$$
A=\frac{1}{V_{t}} \cdot\left(\frac{C_{\text {out }} \cdot t_{p}}{R}\right)^{2}
$$

Substituting numerical value into (8), the result was $\mathrm{A}=100.44 \mathrm{~m}^{2}$.

The above analyses permit the conclusion that the developed method of sizing the reservoir makes it possible to assess the effect of the inflow hydrograph shape on the storage volume and in a relatively simple manner allows for taking into account the stormwater volume distribution nonuniformity in the hydrograph while defining the cross section of the storage chamber.

\section{Conclusions}

The paper presents the method of determining the storage volume of single-chamber rectangular reservoirs based on the nomograph connecting the parameters and the shape (triangular, described by the power function and the gamma distribution) of the inflow from the catchment hydrograph with the cross section of the storage chamber and the orifice diameter. This method is characterized by a high level of accuracy, which is confirmed by the similar values of the $\mathrm{R}=\mathrm{f}\left(\omega, \beta=\beta^{*}, \beta^{*}=\right.$ const) variability obtained by interpolation and by using the numerical simulations in the SWMM program. Based on the calculations presented in the paper, it can be concluded that the mode of the inflow hydrograph parameterization has a significant effect on the relation $\mathrm{R}=\mathrm{f}\left(\omega, \beta=\beta^{*}, \beta^{*}=\right.$ const $)$. The performed calculations showed that the storage volume of the detention reservoir is affected by the shape of the inflow hydrograph. The conducted calculations revealed that the increase in the hydrograph asymmetry coefficient leads to the rise in the required reservoir volume.

The analyses presented in the paper show that the derived formulas and the developed nomographs permit a relatively quick design of the reservoir, which is confirmed by the included calculation examples. Moreover, the methodology of developing nomographs and particular relations discussed in the paper is of a universal character and can be applied in other cases.

\section{References}

Akan, O.A. (1990). Single outlet detention pond analysis and design, Journal of Irrigation and Drainage Engineering, 116, 4, pp. 527-536.

Akan, O.A. \& Houghtalen, R. (2003). Urban hydrology, hydraulics, and stormwater quality. Engineering applications and computer modeling, John Wiley \& Sons, New Jersey 2003.

Aron, G. \& Kibler, D.F. (1990). Pond sizing for rational formula hydrographs, Water Resources Bulletin, 26, 2, pp. 255-258.

ATV A-118 (1990). Hydraulische Bemessung und Nachweis von Entwässerungssystemen, ATV - Regelwerk, Arbeitsblatt A 118, Hennef.

Bach, P.M., Rauch, W., Mikkelsen, P.S., McCarthy, D.T. \& Deletic, A. (2014). A critical review of integrated urban water modelling - Urban drainage and beyond, Environmental Modelling \& Software, 54, pp. 88-107.

Baker, W.R. (1979). Stormwater detention design for small drainage areas, Public Works, 108, 3, pp. 75-79.

Banasik, K., Krajewski, A., Sikorska, A. \& Hejduk, L. (2014). Curve number estimation for a small urban catchment from recorded rainfall - runoff events, Archives of Environmental Protection, 40, 3, pp. 75-86.

Basha, H.A. (1995). Routing equations for detention reservoirs, Journal Hydraulic Engineering, 121, 12, pp. 885-888.

Burszta-Adamiak, E. (2012). Analysis of stormwater retention on green roofs, Archives of Environmental Protection, 38, 4, pp. $75-86$, pp. 3-13.

Burton, K.R. (1980). Stormwater detention basin sizing, Journal Hydraulics Division, 106, 3, pp. 437-439.

Chow, V.T., Maidment, D.R. \& Mays, L.W. (1988). Applied hydrology, McGraw-Hill, Singapore 1988.

Dayarante, S.T. \& Perera, B.J.C. (2004). Calibration of urban stormwater drainage models using hydrograph modeling, Urban Water Journal, 1, 4, pp. 283-297.

Dayarante, S.T. \& Perera, B.J.C. (2008). Regionalisation of impervious area parameters of urban drainage models, Urban Water Journal, 5, 3, pp. 231-246.

Djordjević, S., Prodanović, D., Maksimović, Č., Ivetić, M. \& Savić, D. (2005). SIPSON - Simulation of Interaction between Pipe flow and Surface Overland flow in Networks, Water Science \& Technology, 52, pp. 275-283. 
Donahue, R.J. \& McCuen, R.H. (1981). Comparison of detention basin planning and design models, Journal Water Resources Planning Management Division, 107, 2, pp. 385-400.

Dziopak, J. (1997). Multi-chamber storage reservoirs in the sewerage system, Monograph, Oficyna Wydawnicza Politechniki Częstochowskiej, Częstochowa 1997.

Dziopak, J. (1984). Mathematical model of storm storage reservoir, monograph, Wydawnictwo Politechniki Krakowskiej, Kraków 1984. (in Polish)

Dziopak, J. \& Słyś, D. (2006). Physical and mathematical model of gravitation - pump reservoir in sewage system, Environment Protect Engineering, 32, 2 , pp. 128-137.

Fenton, J.D. (1992). Reservoir routing, Hydrological Sciences Journal, 37, 3, pp. 233-246.

Fiorentini, M. \& Orlandini, S. (2013). Robust numerical of the reservoir routing, Advances in Water Resources, 59, pp. 123-132.

Froehlich, D.C. (2009). Graphical sizing of small single - outlet detention basins in the Semiarid Southwest, Journal of Irrigation and Drainage Engineering, 135, 6, pp. 779-790.

Gomez, M., Vasquez, S. \& Sanchez, H. (2001). Pre-sizing of detention basins. 4th International Conference NOVATECH - Innovative technologies in urban drainage (pp. 555-562), 25-27 July 2001, Lyon 2001.

Graber, D.S. (2009). Generalized numerical solution for detention basin design, Journal of Irrigation and Drainage Engineering, 135, 4, pp. 487-492.

Guo, J.C.Y. (1999). Detention basin sizing for small urban catchments, Journal of Water Resources Planning and Management, 125, 6, pp. 380-382.

Guo, J.C.Y. (2004). Hydrology - based approach to storm water detention basin design using new routing schemes, Journal of Hydrologic Engineering, 2004, 9, 4, pp. 333-336.

Gironàs, J., Niemann, J., Roesner, L.A., Rodriguez, F. \& Andrieu, H. (2009). A morpho-climatic instantaneous unit hydrograph model for urban catchments based on the kinematics wave approximation, Journal of Hydrology, 377, 3-4, pp. 317-334.

Hager, W. \& Sinninger, R.O. (1985). Flood storage of reservoir, Journal of Irrigation and Drainage Engineering, 111, 1.

Hong, Y.M. (2008). Graphical estimation of detention pond volume for rainfall of short duration, Journal of Hydro - environment Research, 2, 2, pp. 109-117.

Hong, Y.M., Yeh, N. \& Chen, J.Y. (2006). The simplified methods of evaluating detention storage volume for small catchment, Ecological Engineering, 26, 4, pp. 355-364.
Kessler, A. \& Diskin, H.M. (1991). The efficiency function of detention reservoirs in urban drainage systems, Water Resources Research, 27, 3, pp. 253-258.

Kisiel, A., Kisiel, J, Malmur, R. \& Mrowiec, M. (2008). Retention tanks as key elements modern drainage systems, Technical Journal Environment, 105, 1, pp. 41-63. (in Polish)

Kisiel, A. (2007). Optimus - EP storage reservoir with a vacuum chamber filled by a system of suction and force pumps, Environment Protection Engineering, 33, 3, pp. 47-54.

Licznar, P. (2004). Rainfall erosivity prediction in Poland on the basis of monthly precipitation totals, Archives of Environmental Protection, 30, 4, pp. 75-86, pp. 29-39.

Licznar, P. (2013). Reservoir dimensioning based on the synthetic rainfall time series, Ochrona Środowiska, 35, 2, pp. 27-32.

Linsley, R.K., Kohler, M.A. \& Paulhus, J.L. (1958). Hydrology for Engineers, Mc Graw - Hill, New York 1958.

Malmur, R. (2011). Analysis of hydraulic operations of transfer reservoir, Rocznik Ochrona Środowiska, 131, 1, pp. 2001-2014. (in Polish)

McEnroe, B.M. (1992). Preliminary sizing of detention reservoirs to reduce peak discharges, Journal of Hydraulic Engineering, 118, 11, pp. 1540-1549.

Mrowiec, M. (2009). The effective dimensioning and dynamic regulation sewage reservoirs, monograph, Wydawnictwo Naukowe Politechniki Częstochowskiej, Częstochowa 2009. (in Polish)

Seo, J., Choi \& N.-J., Schmidt, A.R. (2013). Contribution of directly connected and isolated impervious areas tourban drainage network hydrographs, Hydrology and Earth System Sciences, 17, pp. 3473-3478.

Shuster, W.D., Bonta, J., Thurston, H., Warnemuende, E. \& Smith, D.R. (2005). Impacts of impervious surface on watershed hydrology: A review, Urban Water Journal, 2, 4, pp. 263-275.

Szeląg, B. \& Kiczko, A. (2014). The graphic method of sizing pipe reservoir for short, high - intensity rainfalls, Annals of Warsaw University of Life Sciences - SGGW Land Reclamation, 46, 3, pp. 221-232.

Taiwan Provincial Government Water Resources Department (1993). Study on the characteristics of triangular unit hydrograph, pp. 5-12. (in Chinese)

United States Department of Agriculture (1986). Urban hydrology for small watersheds. Technical Release 55 (TR-55) (Second Edition ed.). Natural Resources Conservation Service, Conservation Engineering Division.

\title{
Metoda wymiarowania jednokomorowego zbiornika retencyjnego w zlewniach miejskich
}

\begin{abstract}
Streszczenie: W artykule przedstawiono metodę projektowania jednokomorowych prostopadłościennych zbiorników retencyjnych opierającą się o nomogramy wiążące parametry i kształt hydrogramu dopływu (trójkątny, potęgowy i opisany rozkładem gamma) do zbiornika oraz charakterystyki hydrauliczne komory akumulacyjnej i spustu. Do opracowania nomogramów tych wykorzystano wyniki obliczeń numerycznych równania różniczkowego bilansu objętości ścieków deszczowych w programie SWMM (Storm Water Management Model). Wykonane analizy potwierdzają wysoką zgodność wyników obliczeń pojemności zbiorników przeprowadzonych w powyższym programie oraz przy pomocy opracowanych nomogramów. Zamieszczone w pracy przykłady obliczeniowe potwierdzają aspekty aplikacyjne przedstawionej metody projektowania zbiornika retencyjnego. Ponadto, na podstawie przeprowadzonych analiz stwierdzono, że największy wpływ na pojemność akumulacyjną zbiornika ma hydrogram dopływu opisany rozkładem gamma a najmniejszy hydrogram, którego kształt w fazie przyboru i opadania jest wyrażony funkcją potęgową.
\end{abstract}

